\title{
Abrir la cultura
}

Noemí Lera Cano | Dirección de Servicios Públicos Digitales, E.P.E. Red.es

URL de la contribución <www.iaph.es/revistaph/index.php/revistaph/article/view/3953>

¿Por qué los datos abiertos? La respuesta es fácil, porque favorecen la circulación de información hacia los agentes económicos y la ciudadanía, porque los datos abiertos constituyen una materia prima para crear productos, servicios y conocimiento y porque los datos abiertos generan tejido empresarial y productivo.

Detrás de esta respuesta, en apariencia sencilla, hay un reconocimiento implícito a los datos como un activo de enorme valor, que viene acompañado de un impulso institucional, liderado en parte desde Europa con el desarrollo del Mercado Único Digital y la Economía del Dato.

En España no hemos permanecido ajenos a este modelo de negocio, ya en el año 2012, la Escuela de Organización Industrial (EOI) y MediaLab Prado publicaron un informe (VICENTE ROMERAL, 2012) en el que identificaron la cadena de valor de los datos y los retos y necesidades para consolidar la economía del dato, que próximamente recibirá un impulso de la Administración al convertirse en uno de los cinco pilares de la nueva Agenda Digital para España.

El impacto social y económico que tendrá la economía del dato para los distintos agentes involucrados está pendiente de determinarse, pero sí sabemos que los datos abiertos tendrán un papel fundamental en esta nueva economía.

Las instituciones culturales se incorporaron formalmente a este sector hace un par de años, con la entrada en vigor de la Ley 18/2015, aunque muchas de ellas llevaban ya varios años publicando datasets e incluso reutilizando sus propios datos. Es cierto que las organizaciones se enfrentan a retos parecidos a la hora de abrir sus datos, sin embargo, el ámbito de la cultura tiene connotaciones propias y aún no ha cerrado el debate sobre: la gratuidad o no de los datos, tipos de licencias para la reutilización o las consideraciones que pueden tener los metadatos que acompañan a los recursos.

El ámbito de la cultura tiene, además, una composición institucional compleja: instituciones públicas dependientes de todos los niveles de la Administración, organismos autónomos con patrimonio y tesorería propios, entidades privadas que reciben fondos públicos y fundaciones totalmente privadas. En medio de este panorama complejo, podemos situar algunos datos objetivos, que ayuden a ordenar el debate.

El sector de actividad económica derivado de la reutilización de datos abiertos se denomina sector infomediario, y en los informes elaborados por el Observatorio Nacional de Tecnologías de las Telecomunicaciones y de la Sociedad de la Información (ONTSI) y por la Asociación Multisectorial de la Información (ASEDIE), podemos encontrar algunas cuestiones interesantes:

$>$ Los datos abiertos crean cultura. Los datos publicados por terceros pueden ser reutilizados por personas, físicas o jurídicas, para crear nuevos productos y servicios culturales. El estudio del ONTSI mencionado anteriormente calcula que el subsector cultural supone un $13 \%$ del sector infomediario.

El estudio de ASEDIE permite conocer un poco más en detalle a las empresas que actúan en el ámbito cultural: contribuyen con el $5 \%$ del empleo del sector, suscriben el $9 \%$ del capital, pero representan únicamente el $2 \%$ de las ventas del sector.

> Dónde buscar datos culturales. En el Catálogo Nacional de Datos Abiertos hay más de 16.000 conjuntos de datos, pero sólo el $6 \%$ están catalogados como datos relativos a la cultura y el ocio, los cuales, en la gran mayoría de los casos, provienen de comunidades autónomas 
y ayuntamientos. Son muy pocas las instituciones culturales que aparecen como publicadoras de conjuntos de datos: la Biblioteca Nacional de España, el Instituto Nacional de las Artes Escénicas y de la Música y la Fundación Lázaro Galdiano. Esta radiografía es incompleta, pero refleja los datos que están libremente disponibles, sin ninguna restricción en el uso, para su reutilización por cualquier persona interesada.

Es cierto que las instituciones culturales publican cada vez más datos, un buen ejemplo son los más de 2 millones de recursos publicados en Europeana provenientes de más de 80 instituciones españolas, sin embargo, en la inmensa mayoría de los casos, la reutilización de esos recursos tiene restricciones, casi siempre asociadas al uso comercial de los mismos.

No hay que olvidar la importancia creciente que tiene la filosofía colaborativa, que va desde proyectos como Wikimedia, con datos reutilizables de textos originales, citas, libros, imágenes o recursos didácticos, hasta proyectos de investigación como Mnemosine donde las bases de datos e incluso las herramientas usadas en su trabajo están abiertas a la reutilización:

$>$ La calidad de los datos culturales. Los participantes en el estudio elaborado por el ONTSI (CARACTERIZACIÓN, 2016) realizaron una valoración de los datos abiertos según su tipología, tomando en consideración aspectos tales como: completitud, información adicional, contexto y metodología, formatos, etc. Hay que decir que los datos culturales no han suspendido valoración en ninguna de las categorías planteadas, a diferencia de los datos de economía, hacienda y empleo que son los peor valorados por los reutilizadores. Las empresas han valorado muy positivamente que los datos culturales están en formatos estructurados, que no se requiere un registro previo y sobre todo, la gratuidad.

$>$ El impacto de los datos culturales. Aunque no existen indicadores de referencia para el ámbito cultural, la valoración debe realizarse teniendo en cuenta distintas dimensiones, como la económica, que se puede ligar al desarrollo del sector turístico, la social, por su incidencia en servicios públicos como la educación, o la tecnológica, por la capacidad de innovar.

Tres últimas ideas antes de concluir:

En primer lugar, la Administración pública es un potencial reutilizador de sus propios datos, tal y como nos recuerda el desafío puesto en marcha por el Programa Aporta: "El valor del dato para la Administración" en el que se premiarán aquellos prototipos que, usando datos abiertos, impliquen una mejora de la eficiencia interna.

En segundo lugar, de las instituciones públicas culturales cabe esperar no sólo que abran sus datos, sino que además impulsen de forma activa su reutilización, en este sentido es destacable el espacio BNELab presentado recientemente, por el efecto tractor e inspirador que debe tener para el sector y por colocar a la Biblioteca Nacional de España a la altura de las instituciones europeas de referencia en estas prácticas.

Por último, la apertura de datos debe realizarse como resultado de una reflexión previa y de la toma de decisiones estratégicas, técnicas y operativas, sólo de esta forma se realizará de forma eficiente y sostenible en el tiempo.

\section{BIBLIOGRAFÍA}

- VICENTE ROMERAL, J. L. DE (2012) Sectores de la nueva economía 20+20. Economía del dato. Madrid: Fundación EOI, 2012 <https://www.eoi.es/es/savia/publicaciones/20709/ sectores-de-la-nueva-economia-2020-economia-del-dato> [Consulta: 14/07/2017]

- CARACTERIZACIÓN del sector infomediario en España. Edición 2016. s.l.: ONSI, Red.es, 2016, p. 84 <http://www.ontsi.red.es/ontsi/sites/ontsi/files/Estudio\%20 de $\% 20$ Caracterizaci $\%$ C3\%B3n\%20del\%20 Sector $\% 20$ Infomediario\%202016_0.pdf> [Consulta: 14/07/2017]

- SECTOR infomediario (V Edición) [en línea] ASEDIE, 2017 $<w w w$.asedie.es/assets/informe-sector-infomediario--2017. pdf> [Consulta: 28/09/2017] 